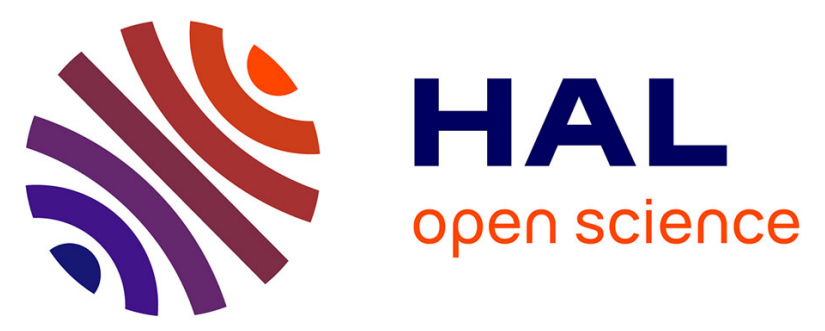

\title{
What ecologists should know before using land use/cover change projections for biodiversity and ecosystem service assessments
}

Cécile H Albert, Mathilde Herve, Marianela Fader, Alberte Bondeau, Agathe Leriche, Anne-Christine Monnet, Wolfgang Cramer

\section{To cite this version:}

Cécile H Albert, Mathilde Herve, Marianela Fader, Alberte Bondeau, Agathe Leriche, et al.. What ecologists should know before using land use/cover change projections for biodiversity and ecosystem service assessments. Regional Environmental Change, 2020, 20 (3), pp.106. 10.1007/s10113-02001675-w . hal-02927830

\section{HAL Id: hal-02927830 \\ https://hal-amu.archives-ouvertes.fr/hal-02927830}

Submitted on 2 Sep 2020

HAL is a multi-disciplinary open access archive for the deposit and dissemination of scientific research documents, whether they are published or not. The documents may come from teaching and research institutions in France or abroad, or from public or private research centers.
L'archive ouverte pluridisciplinaire HAL, est destinée au dépôt et à la diffusion de documents scientifiques de niveau recherche, publiés ou non, émanant des établissements d'enseignement et de recherche français ou étrangers, des laboratoires publics ou privés. 


\title{
What ecologists should know before using land use/cover change projections for biodiversity and ecosystem service assessments
}

\author{
Cécile H. Albert ${ }^{1}$ - Mathilde Hervé ${ }^{1} \cdot$ Marianela Fader $^{1,2} \cdot$ Alberte Bondeau $^{1} \cdot$ Agathe Leriche $^{1}$. \\ Anne-Christine Monnet ${ }^{1} \cdot$ Wolfgang Cramer $^{1}$
}

\begin{abstract}
Scenarios of biodiversity and ecosystem services (BES) are key for decision-makers to understand the consequences of future environmental change on BES. Though a major driver of terrestrial biodiversity loss, land use and land cover changes (LUCC) have been largely overlooked in previous BES assessments. But ecologists lack practical guidance for the general use of LUCC projections. We review the practices in use in LUCC-driven BES assessments and summarize the questions ecologists should address before using LUCC projections. LUCC-driven BES scenarios rely on a substantial set of different socioeconomic storylines (> 200 for 166 papers). Studies explore different futures, but generally concentrate on projections obtained from a single LUCC model. The rationale regarding time horizon, spatial resolution, or the set of storylines used is rarely made explicit. This huge heterogeneity and low transparency regarding the what, why, and how of using LUCC projections for the study of BES futures could discourage researchers from engaging in the design of such biodiversity scenarios. Our results call on those using LUCC projections to more systematically report on the choices they make when designing LUCC-based BES scenarios (e.g. time horizon, spatial and thematic resolutions, scope of contrasted futures). Beyond the improvement of reliability, reproducibility, and comparability of these scenarios, this could also greatly benefit others wanting to use the same LUCC projections, and help land use modellers better meet the needs of their intended audiences. The uncertainties in LUCC-driven BES futures should also be explored more comprehensively, including different socioeconomic storylines and different LUCC models, as recommended in studies dealing with climate-driven BES futures.
\end{abstract}

Keywords Biodiversity modelling $\cdot$ Ecosystem services $\cdot$ Scenarios $\cdot$ Storylines $\cdot$ Global change $\cdot$ Land cover $\cdot$ Species richness $\cdot$ Ecological processes

Cécile H. Albert and Mathilde Hervé contributed equally to this work.

Communicated by Christopher Reyer

Electronic supplementary material

(https://doi.org/10.1007/s10113-020-01675-w)

\section{Cécile H. Albert}

cecile.albert@imbe.fr

Mathilde Hervé

hervemathilde@hotmail.fr

Marianela Fader

Fader@bafg.de

Alberte Bondeau

alberte.bondeau@imbe.fr

Agathe Leriche

agathe.leriche@imbe.fr

Anne-Christine Monnet

monnet.annechristine@gmail.com

Wolfgang Cramer

wolfgang.cramer@imbe.fr

Aix Marseille Univ, CNRS, Avignon Univ, IRD, IMBE,

Aix-en-Provence, France

International Centre for Water Resources and Global Change

(UNESCO), German Federal Institute of Hydrology, Koblenz, DE,

Germany 


\section{Introduction}

Decision-makers need robust scenarios* (see glossary) for biodiversity and ecosystem services (BES), i.e. information regarding plausible* futures of BES, assuming different policy alternatives and future environmental change (IPBES 2016; Visconti et al. 2016) (Box 1). BES scenarios have undergone substantial development in the last decades (IPBES 2016). However, most studies have investigated the impacts of climate change only while accounting to a lesser degree for other drivers* of ecosystem change, notably land use and land cover changes (LUCC) (Titeux et al. 2016; Morán-Ordóñez et al. 2018). Yet, LUCC have been the dominant driver of terrestrial biodiversity loss during the past century in much of the world (Pereira et al. 2010), and it is likely to remain a major threat in the future (IPBES 2019). LUCC will also interact with the impacts of climate change on ecosystems (Radinger et al. 2016). Recent syntheses have thus recommended that LUCC scenarios should receive greater attention during assessments of future changes in BES (Titeux et al. 2016). This should be facilitated by recent progress made regarding the reliability and accessibility of LUCC projections* (Alexander et al. 2017) and through the efforts of the IPBES (International Platform on Biodiversity and Ecosystem Services) Task Force on Scenarios and Models to better integrate LUCC and BES futures (Kim et al. 2018) (see Fig. 1 for a summary of ongoing collaborative research).

Despite these efforts, ecologists who wish to engage in such LUCC-based BES scenarios sorely lack a synthesis of

Box 1 What are land use change-driven biodiversity scenarios?

Scenarios for the assessment of changing biodiversity and ecosystem services (BES) are typically constructed on the basis of societal narratives alongside formalized spatial projections of future environmental conditions (Pereira et al. 2010). First, to explore different visions of the future and the associated changes in key indirect drivers of ecosystem change, such as human socioeconomic development and associated greenhouse gas emissions, storylines are developed (see Glossary). These storylines are often qualitative and imply narrative descriptions of plausible or goal-oriented socioeconomic development pathways, presented as sets of easily distinguishable alternatives. Then, for each storyline, quantitative and spatial projections, i.e. maps, are developed for the direct drivers of ecosystem change with simulation models or statistical extrapolations of current trends. Drivers include the physical environment such as climate (e.g. temperature) and direct human activities such as land use/cover change (LUCC). One given storyline may correspond to different spatial projections of climate or LUCC, depending on the model and the assumptions used to make this translation. Finally, the drivers of ecosystem change (e.g. climate and LUCC projections) are used as inputs to BES models (e.g. species distribution models, ecosystem services mapping), leading to BES scenarios. The steps from socioeconomic storylines to BES scenarios are typically conducted by different research communities (e.g. economists, climate and land-system scientists, ecologists) which may impede the overall workflow (Fig. 1). practical recommendations for the use of LUCC projections; despite various notes about the topic, scattered in the land science literature-literature that ecologists are not familiar with - and in institutional reports. The present work proposes such a synthesis. First, we review the practices currently in use in LUCC-driven BES assessments by asking two questions: What types of BES assessments are made when LUCC are considered? What are the LUCC projections that are commonly used to investigate BES futures? Second, we summarize the points of vigilance raised by these practices by asking the question: What are the main characteristics (temporal, thematic, spatial, and socioeconomic) of these LUCC projections, and what do they imply for BES assessments? Third, we suggest priority actions to improve the use of LUCC projections by ecologists. With our user-centred approach, we necessarily miss LUCC projections that have not yet been used in the context of BES, but reviewing these is outside the scope of the present work.

We reviewed a selection of 166 papers (see Online Resource 1). Half of them represent the most recent literature on LUCCdriven BES scenarios (88 papers published after 2015); the other half represent the most cited literature on the subject (78 papers published between 1993 and 2013, with up to 4800 citations). The figures provided below show data from the first sample ("recent literature"), and we explicitly refer to data from the second sample ("influential literature") where we found noticeable differences among both samples. We have worked on these two subsets of the literature because they represent both the work and LUCC projections that have been the most influential in the past decades, and the most recent progresses on this topic.

We use the term "scenario*" when dealing with a potential future in the broad sense (e.g. a story, a figure, a map); we use "storyline*" for the socioeconomic description and "projection*" for the spatial expected realization of land use/cover futures; we use the term "family*" for groups of scenarios that result from the same project or the same LUCC model.

\section{A single conceptual model for various types of biodiversity futures}

The reviewed papers show that BES assessments can take many different forms and address multiple questions. Various indicators are used to investigate the futures of biodiversity, but indirect assessments - that make no explicit links to specific organisms - remain the most frequent; for instance, 28/88 papers measure the availability or quality of natural habitats (e.g. Zarandian et al. 2017). Direct assessments are largely dominated by the modelling of species geographic distributions (18/88 papers), with tools like BIOMOD (e.g. Visconti et al. 2016) or MaxEnt (e.g. Riordan et al. 2015). The statistical extrapolation* of species richness from local land use intensities with the global database PREDICTS (8/88, e.g. Newbold et al. 


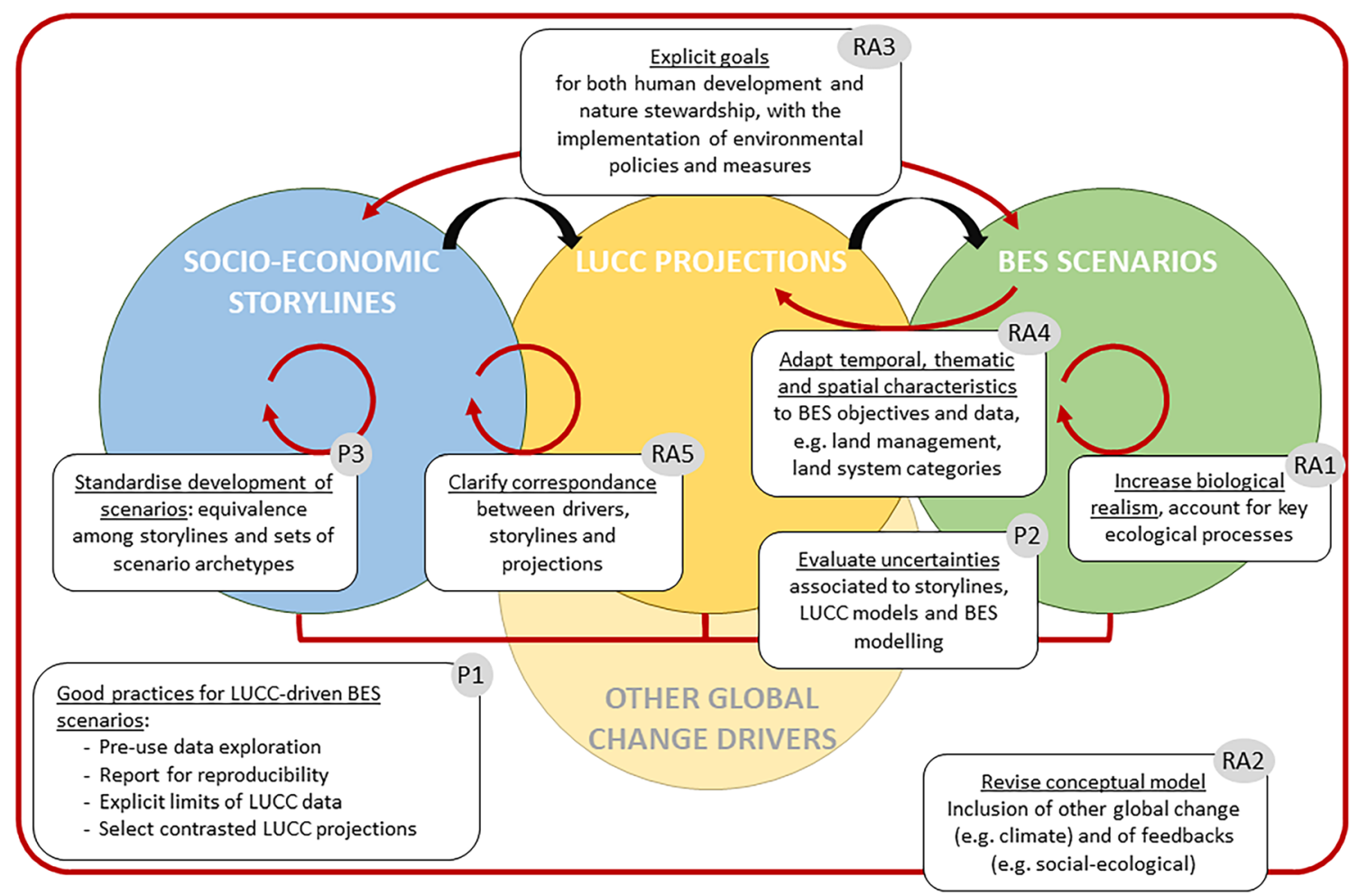

Fig. 1 Workflow from socioeconomic storylines to biodiversity scenarios and the associated land use change research agenda. Black arrows represent the classical modelling output-input flow from socioeconomic storylines to biodiversity and ecosystem services (BES) scenarios through land use/cover change (LUCC) projections. Key conceptual and methodological improvements recommended obtaining more reliable and policy-relevant BES scenarios, and that are part of the ongoing research agenda to better integrate LUCC and BES futures are represented by the boxes and the associated red arrows. They are labelled as "priorities" (Px) for the three points highlighted as urgently needed by our review work and "research agenda" (RAx) for the others

such as land use/cover and climate change (Sirami et al. 2017). In an improved conceptual model, land use/cover could appear as both a driver of biodiversity loss and an opportunity for nature conservation and also as both a driver and a consequence of climate change (IPBES 2016) (Fig. 1, RA2).

\section{Land use change projections used to explore biodiversity futures differ with spatial extent}

The 88 recent studies refer to 231 different LUCC storylines (more than 400 if we account for both recent and influential papers), most of these storylines being encountered only once (88\%, Fig. S1). The main determinant behind the use of this plethora of LUCC storylines is spatial scale; we thus separated the studies into two groups based on their geographic extent: studies at global, continental, or national scale vs. studies at local or subnational scale.

In global to national assessments (28/88 papers), the most frequently encountered storylines come from a handful of different sources such as the IPCC Special Report on Emission Scenarios (SRES; Nakićenović et al. 2000) (Fig. S1 and Table S2). These storylines have been translated into multiclass LUCC spatial projections with various models (e.g. 
IMAGE, EURURALIS, GLOBIO 3, see Table S1 for acronyms) in the context of large international research projects (e.g. European project ATEAM, Metzger et al. 2004; or ALARM, Spangenberg et al. 2012) or global assessments (e.g. Millennium Ecosystem Assessment, hereafter MA, 2005). In the recent literature, the decades-old SRES and storylines from the ALARM project are still used frequently, but the storylines for the forthcoming IPCC Sixth Assessment Report, namely the shared socioeconomic pathways* (SSPs; O'Neill et al. 2017) and the associated Representative Concentration Pathways (RCP; IPCC 2014), are increasingly used in broad-scale BES assessments (Fig. S1). These storylines are typically developed for the evaluation of scenarios for global socioeconomic agenda setting and policy design, mostly in relation to climate change issues. They are little connected - even the most recent - to biodiversity and ecosystem services (Kok et al. 2017), hence the IPBES development of a new generation of nature-centred scenarios (Rosa et al. 2017) (Fig. 1, RA3). Indeed, in the current IPCC framework, land conversion is large, both in scenarios that lack consideration for sustainability and in strong climate mitigation scenarios. IPBES scenarios should thus explore the synergies and antagonisms between nature conservation and other societal goals (Popp et al. 2017).

In the subnational to local assessments (60/88), many different storylines and LUCC projections are used, either locally defined projections or downscaled versions of global projections. Often, they are explicitly tailored to support local policy design and implementation. These storylines and LUCC projections are either based on participatory approaches such as workshops or surveys with local stakeholders (13/88), or directly derived from local development plans $(2 / 88)$. Sometimes, the global storylines (e.g. from the IPCC or ALARM) are used as set boundaries within which local futures can take place (10/88); statistical downscaling* procedures (e.g. Radinger et al. 2016) or stakeholder-based methods to account for local context (e.g. Brunner et al. 2016) are used. Many local/subnational studies (33/88) rely on hypothetical LUCC scenarios, i.e. scenarios that are defined by the scientists to test their hypotheses or the sensitivity or their models, but are not directly designed (or not explicitly) to be informative for decision-making. The justification for using such expert-based scenarios is not always explicitly stated (but see Zarandian et al. 2017).

The modelling approaches used to obtain local/subnational LUCC projections are highly diverse ( $>25$ different models). They include multi-class land use change simulators such as CLUE-S (Jiang et al. 2017), or IDRISI-LCM (Zhou et al. 2017), simulators focusing on specific land types such as LANDIS-II for forests (Thompson et al. 2016) or FUTURES for urban expansion (Pickard et al. 2017), or even agent-based models that account for individual or group decision-making (Dislich et al. 2018). Overall, it is challenging to draw a general picture, due to the diversity of LUCC projections used to make BES scenarios at local/ subnational level, and also due to the low transparency and consistency regarding their production. Despite this apparent diversity of modelling approaches, recent reviews also suggest that existing land use models, including agent-based models, take a very narrow range of approaches and leave many important facets of human decision-making unexplored (Groeneveld et al. 2017).

\section{Four things ecologists should know before using land use change projections}

1) Temporal characteristics of land use change projections and the ecological forecast horizon

When designing LUCC-based BES scenarios, a first question to address is how far into the future it is relevant to go.

Most reviewed studies (45/88) have made BES forecasts for medium-term time horizons* (2030-2050), while fewer used short-term (present-2025, 15/88) or long-term ( $>2080$, $6 / 88$ ) time horizons. We encountered 24 different longestterm time horizons, presented either as a date (e.g. 2031) or as a time interval (e.g. +10 years); 12/88 studies gave no specific time frame, $7 / 88$ of which presented scenarios based on relative changes (e.g. \% increase), and $5 / 88$ gave no details. These time horizons are rarely justified in explicit terms, and the great heterogeneity encountered may largely reflect practical constraints such as data availability (Table S2). The availability of LUCC projections, particularly those designed for long time horizons (ex. 2080, 2100 or > 2100) for consistency with climate change projections (de Chazal and Rounsevell 2009), does not necessarily justify their use to construct BES scenarios, for two main reasons:

First, socioeconomic storylines from which LUCC projections are derived are potentially too conservative even in the medium term as they do not account for potential disruptions by socioeconomic or natural disasters. This is illustrated by broad-scale LUCC projections that tend to diverge more quickly over the period 2000-2040 than after 2040 (Fig. S2, Alexander et al. 2017). Even the most basic scenario drivers (e.g. human population, technological progress, room for yield improvement) are highly uncertain over the course of 50-100 years (Popp et al. 2017). Local trajectories of land management, policies, and political changes largely depend on individual decisions that are context-dependent and difficult to predict (de Chazal and Rounsevell 2009). Finally, sudden large-scale events such as wars, natural disasters, or pandemics can trigger major changes in the drivers of socioeconomic storylines that are rarely considered (Jepsen et al. 2015). While the purpose of scenario-based modelling is to represent the uncertainties associated with the evolution of the 
system, socioeconomic scenarios may not be able to explore as wide a range of possible futures beyond 2040 as expected.

Second, uncertainties in storylines are exacerbated when they are translated into quantitative spatially explicit LUCC projections (Rounsevell and Metzger 2010), and further propagated towards biodiversity outcomes, which adds to BES modelling uncertainties (e.g. poor-quality BES input data, omission of key processes; IPBES 2016). Thus, beyond a certain point in time (equivalent to the "ecological forecast horizon" of Petchey et al. 2015), such accumulations of uncertainty can lead to uninterpretable results. Whether a time horizon for BES scenarios is appropriate also depends on the type of application. Some immediate needs of policymakers may endorse short/medium-term time horizons (5-20 years). In our review, local/subnational studies that deal with land management policies tend to focus on the short term. Long time horizons could be more appropriate when dealing with climate change mitigation or adaptation, or when making broad-scale assessments of LUCC impacts on BES. In this case, it seems crucial to account for both climate and LUCC jointly, yet six studies we reviewed investigate LUCC in the long term without accounting for climate change.

2) Thematic* resolution of land use change projections and adequacy with biodiversity modelling

When designing LUCC-based BES scenarios, the second question to address is how should land use/cover be represented (number and type of land use/cover classes in LUCC projections).

In our selection of studies, global/national assessments tend to focus on multi-sectoral LUCC (21/28) while subnational/ local assessments tend to focus on sectoral changes only (47/ $60)$ such as croplands or forest management options (28), urban development (7), biodiversity conservation (5), restoration (3), offsetting strategies (2), or the management of multiple ecosystem services (2).

When there is no single optimal land use/cover classification scheme for BES modelling, then the adequacy of a land use/cover classification for BES modelling should be considered carefully. First, few and general land use/cover classes (e.g. "forest") can hide very different realities, leading to poor estimates of the area dedicated to each class and the BES that rely on it (Sexton et al. 2016). For example, forest cover is often poorly related to species diversity if species-poor plantations or post-disturbance shrublands replace semi-natural forests (Brockerhoff et al. 2008). Second, the impacts of LUCC on BES strongly depend on specific changes in land management practices (i.e. changes occurring within a single land use/cover class) and their intensity (e.g. irrigation, fire management) (Newbold et al. 2016; Hervé et al. 2016). Third, some land use/cover classes that represent relatively small fraction of land surfaces (e.g. urban classes, linear infrastructures) are often missing from LUCC projections (e.g. urban omitted in 2 of the 8 families from Table S2). Yet, urban areas and impervious infrastructures are quickly expanding (Seto et al. 2012) and they heavily impact BES both locally and remotely (Eigenbrod et al. 2011; Torres et al. 2016). Fourth, the diversity of existing classification schemes is known to be a major limitation for the compatibility and comparability of projections among "families*" (Sohl et al. 2016). Improved LUCC projections however partly overcome these limitations. They tend to have refined thematic resolutions (e.g. 44 classes in Rickebusch et al. 2011) and to be more interoperable due to data standardization and harmonization (Hurtt et al. 2011). Minority classes (e.g. urban areas) are accounted for by characterizing land surfaces with a set of different layers, each representing the percent of area of a given class. Some also assesses changes in land management, either in terms of land systems, i.e. a new typology of land surfaces that account for both land cover and land management via information on the intensity of this management (e.g. fertilizer input, livestock numbers) from diversified sources of information (e.g. CLU-Mondo, Van Asselen and Verburg 2013), or with management layers such as in the Land-use Model Intercomparison Project (LUH2: http://luh.umd.edu/ data.shtml).

The other side of the coin remains however that refined LUCC models and projections cannot be properly calibrated and validated due to a lack of high-resolution historical data on land use and its drivers. Projections with many different classes also come at the cost of much higher uncertainties regarding the trajectories and spatial distribution of changes of those individual classes.

The applied approach for biodiversity modelling can also be the constraining factor. For many taxa, processes, and ecosystem services, knowledge about their ecological requirements is too limited to be able to inform how many different land cover/use classes relate to them, meaning that a high number of land use classes are not systematically bettersuited to BES modelling and scenarios (Fig. 1, RA4).

3) Spatial characteristics of land use change projections: the "where" matters as much as the "what"

When designing LUCC-based BES scenarios, the third question to address is how the spatial characteristics of LUCC projections interplay with the ecological patterns and processes under investigation. Appropriateness of LUCC projections for BES modelling includes their spatial resolution and the spatial allocation of expected changes, i.e. where changes occur.

A majority of the recent studies (50/88) were conducted at a spatial resolution of $1 \mathrm{~km}$ or less, marking an improvement of resolution compared with the influential papers (only 39/78 $\leq 1 \mathrm{~km}$ ). Still 5/16 regional-scale and 1/44 local-scale studies 
worked at resolutions of $10 \mathrm{~km}$ or coarser, and for 13 studies, we did not find the information.

The ecological relevance of the first generation of available LUCC projections has been criticized for their coarse spatial resolutions of several tens of kilometres (de Chazal and Rounsevell 2009). A coarse grain means that most grid cells, assigned to a single land use/cover class, may actually host several different habitats. Low resolution also makes it more difficult to account for ecological processes that occur over small spatial scales but may play a strong role on the future of BES even over broad spatial extents (e.g. typical seed dispersal ranges from few metres to several kilometres). Downscaling procedures and modelling techniques have partly resolved this issue with LUCC projections now available at global/ continental scale at $1 \times 1 \mathrm{~km}$ or even $250 \times 250 \mathrm{~m}$ (Dendoncker et al. 2006). However, data at higher resolutions (e.g. $30 \times 30 \mathrm{~m}$ ) are not necessarily more accurate when they are interpolated from coarse observations, because the real determinants of variation in land use at those high resolutions are not available (IPBES 2016). LUCC projections with high spatial resolutions also require similar refinement in the spatial accuracy of BES data (e.g. spatial accuracy in the occurrence data used to model the geographic distribution of a species) to avoid erroneous conclusions (McPherson et al. 2006).

For biodiversity assessments, not only the amount but also the spatial arrangement of LUCC matters (Dale et al. 1994). On the one hand, the spatial arrangement of LUCC over broad spatial extent meets long-standing questions in biogeography and macro-ecology. Are some areas - especially biodiversity hotspotsmore at risk than others? Are some facets of BES more at risk than others? If main broad-scale trends seem to be well represented in the different available LUCC models (e.g. urbanization around major cities or along the coasts, Seto et al. 2012; or decline in croplands in less productive areas, Kuemmerle et al. 2016), these models still rarely account for regional differences that can emerge from natural, political, or cultural specificities (Plieninger et al. 2016) or due to socioecological tele-connections and cross-scale feedbacks (Kok et al. 2017). Whether global- or continental-scale LUCC projections can be safely used at regional scale remains uncertain (Houet et al. 2017).

On the other hand, the spatial arrangement of LUCC at fine scale meets long-standing questions typical from landscape ecology. Are some spatial configurations of natural habitat more favourable to BES? How do LUCC affect the connectivity of remnant habitats? Locally, the spatial arrangement of LUCC (e.g. compact vs. dispersed urban growth) translates into the spatial arrangement of available habitat (or habitat connectivity), which is expected to have a strong influence on BES via the maintenance of the fluxes of material and organisms (Gonzalez et al. 2017). Yet, very few of the studies we reviewed (6/88), all subnational/local studies, actually account for refined spatial arrangement of LUCC (e.g. Sushinsky et al. 2013). In addition, most LUCC models optimize the spatial allocation of land use/cover in some way (e.g. based on economical constraints), producing projections that are not necessarily relevant to BES questions.

Additional complexity for modelling biodiversity comes from the strong interdependencies among spatial scales. Biodiversity dynamics at a particular scale are sometimes affected by processes acting at other (broader and finer) scales (Opdam and Wascher 2004). For instance, forest connectivity within a $1 \times 1 \mathrm{~km}$ grid contributes to the species range expansion at national scale (e.g. woodpecker, Gil-Tena et al. 2013).

4) Contrasted storylines vs. a broad range of possible futures

When designing LUCC-based BES scenarios, the fourth question to address is how to pick a collection of contrasted LUCC projections that reflect a diversity of alternative possible futures. The papers we reviewed used between one and more than 10 different LUCC projections (at most $30-50$ when combinations of hypotheses are used), most of them (52/88) using 3 or 4 . The recent papers use on average a higher number of different projections $(\sim 5.4 /$ study) than the influential ones ( $\sim 3.6 /$ study). This is in line with studies showing that the use of around three alternative scenarios facilitates further discussion and selection (Voiron-Canicio 2012).

Behind the idea of a selection of a wide variety of possible futures lies one of the current major problems in LUCC modelling, namely the poor correspondence that exists between socioeconomic storylines and LUCC projections (Harmáčková and Vačkář 2018), and the limited understanding we have on how global LUCC projections depend on socioeconomic drivers (Stehfest et al. 2019) (Fig. 1, RA5). On the one hand, most families* (broadly correspond to different LUCC models) of socioeconomic storylines have been constructed to reflect a diversity of hypothesis regarding how their main socioeconomic drivers (e.g. human population, economic growth, environmental awareness) could change in the future (e.g. quick or slow increase in human population; Fig. 2a). We can represent the differences between the classical storylines (those frequently encountered in our review, see Online Resource 1) along two development axes (global vs. regional and economic vs. sustainable) following the example of the SRES scenarios (A1FI, A2, B1, and B2; Nakićenović et al. 2000). The narratives of the same family are distributed over this space, with the different families overlapping more or less (Fig. 2a). On the other hand, available LUCC projections provide a diversity of potential futures regarding projected net change in area (Popp et al. 2017; Alexander et al. 2017) and different spatial allocations of the changes (de Chazal and Rounsevell 2009). Yet, LUCC projections depend more on the LUCC model than on the underlying storyline, probably due to their different assumptions and parameterizations (Schmitz et al. 2014; Prestele et al. 2016). This 


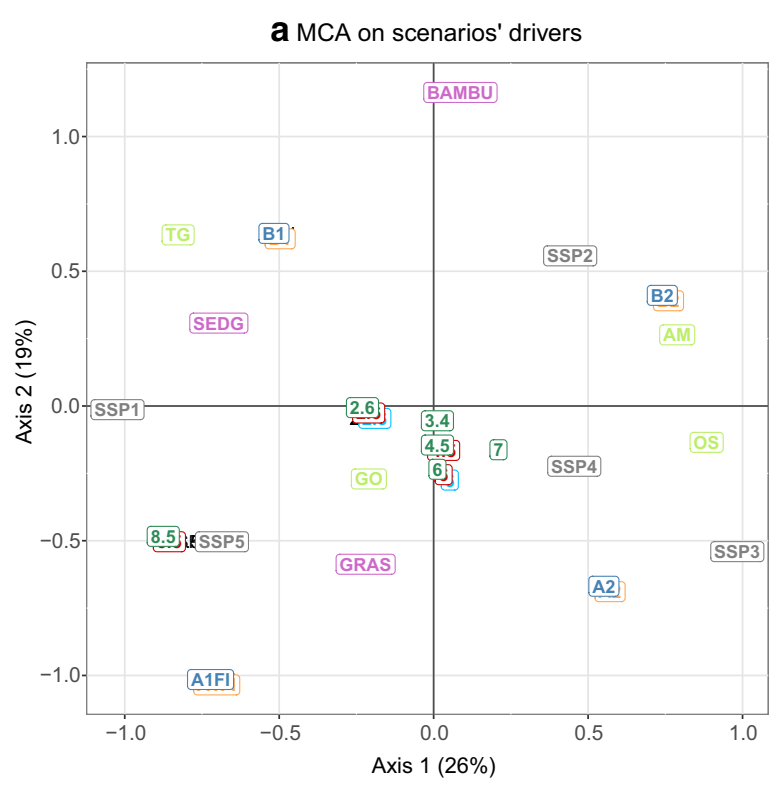

Fig. 2 Comparison of 20 different socioeconomic storylines and a set of 30 associated land use change projections from 8 different families in terms of their drivers and trends. a Land use change projections (colour labels) are displayed along the first two axes of a multiple correspondence analysis (MCA) based on their main drivers. Colours correspond to projections families (see Table S2 for acronyms). Projections based on the same storyline are overlapping. Only the modalities driving the axes (|coordinates $\mid>0.5$ ) are displayed (black labels): development of green technologies (Tech green), increase $(\mathrm{GHG}+)$ or decrease $(\mathrm{GHG}-)$ in greenhouse gases, high $(\mathrm{Pop}+$ ) or low $(\mathrm{Pop}-)$ increase in world population, high $($ Eco growth + ) or low (Eco growth - ) economic growth, fast

means that a given LUCC model (or family) can give very similar LUCC projections for contrasted storylines and that different LUCC models can give very different LUCC projections for a given storyline (Fig. 2b) (Sohl et al. 2016; Alexander et al. 2017). In our example, only the two RCP families and the ATEAM family gather LUCC projections that reflect truly contrasted trends (Fig. 2b).

Such limited correspondence between socioeconomic storylines and LUCC projections means that BES scenarios based on different LUCC projections, that translate different storylines but belong to a single family, may underestimate the extent to which contrasted storylines may result in contrasted BES outcomes, thus poorly reflecting the potential (in)efficiencies of policies. A "multi-family" approach, where LUCC projections are chosen to represent contrasted storylines projected with different LUCC models (e.g. the approach used by the RCPs), would be necessary to account for both socioeconomic uncertainty and structural uncertainty in LUCC models (Sohl et al. 2016). This would however render comparison between BES scenarios difficult, due to the incompatibilities among families of LUCC projections (e.g. resolutions, Sohl et al. 2016). For now, most studies make BES scenarios from LUCC projections from a single family and very few (6/88) combine projections from different families (but see Pereira et al. 2010). b PCA on \% change for main Land types in 2050

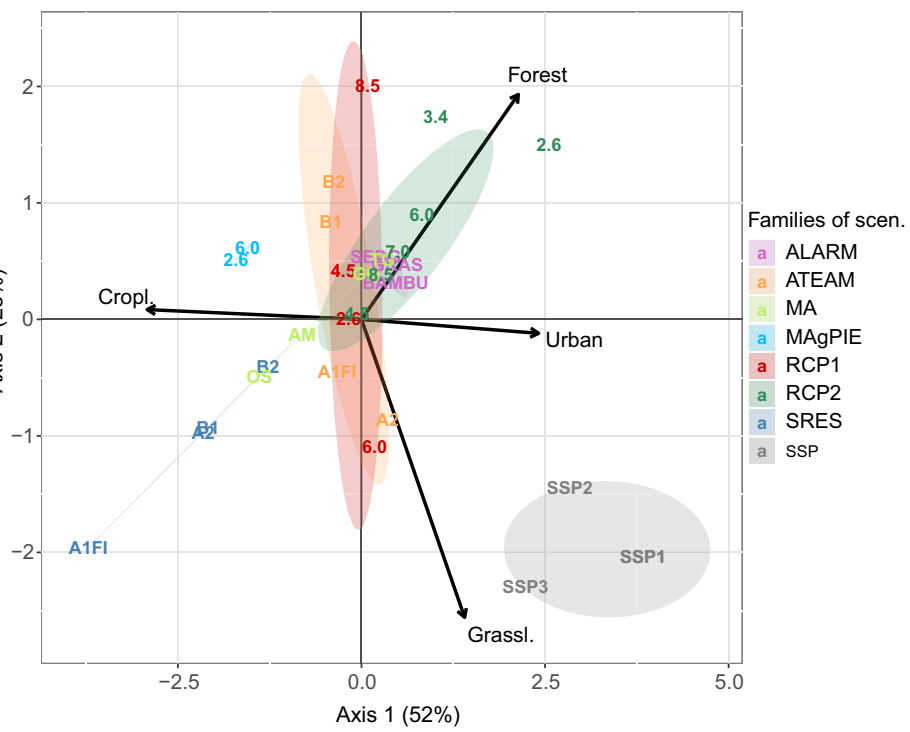

development of technologies (Tech fast) and low environmental awareness (Env awareness -). Note that for the SRES storylines, greenhouse gas emissions are not a driving force but a resultant. Despite we were missing data for SSP4 and SSP5 (the reason why they do not appear in panel b), they have been added to this panel for information. b Land use change projections (colour labels) are displayed along the first two axis of a principal component analysis (PCA) based on their relative change in area for four main land cover types (Cropl. cropland, Grass grasslands, Forest, and Urban, black labels and arrows) over the period 2000-2050. Ellipses encompass $75 \%$ of the variance within each family of projection. See Online Resource 1 for more details

\section{Towards a better future for land use-driven biodiversity scenarios}

By dissecting current modelling practices leading to LUCC-driven BES scenarios, we have shown that they are highly diversified and they go along with a lack of transparency on how and why storylines and LUCC projections have been used to feed ecological modelling. This situation might discourage those wishing to engage in LUCC-driven BES scenarios, such as biogeographers and species distribution modellers. It might also impede discerning the big picture of LUCC impacts on BES along with related opportunities to mitigate global change impacts through land management at local and regional scales. For this reason, we have synthesized key elements of compatibility between LUCC projections and BES assessments and discussed them in the light of the ongoing research agenda on LUCC and BES futures (Fig. 1). Below, we identify three recommendations that require immediate action from those using LUCC projections for BES assessments, without waiting for further developments in LUCC projections. Although these recommendations are not fundamentally new, implementing them could greatly strengthen future BES based on LUCC. 
First, our results call on researchers using LUCC projections for BES assessments to better report on the choices they make when designing LUCC-based BES scenarios to improve the reliability, reproducibility, and comparability of their results (Fig. 1, P1). This could seem trivial, but we encountered few exemplary studies and many imprecise papers in which key information or rationale for using a given set of LUCC projections was simply missing from the main text. LUCCdriven BES assessments should be reported following reproducibility principles such as the FAIR (Findable, Accessible, Interoperable, Reusable) approach (Wilkinson et al. 2016). LUCC projections are not just classical input data; they are the result of preliminary work that bear a whole range of uncertainties. In addition to information on BES data and modelling, assessments should systematically report (1) what LUCC data have been used, with elements on the version, source, and basic characteristics (e.g. spatial and thematic resolution, time horizon, scope of contrasted futures), and details on the underlying LUCC modelling assumptions, (2) whether LUCC data have been used as they are, or adapted (and how) to the case study from broader-scale scenarios, (3) why these data have been used considering the objectives (were these the only data available?), and (4) what were the main weaknesses and limitations of these data regarding the addressed question. Being more explicit about the rationale, and the data and their limits, even when data have been used "by default" (i.e. because they were the only available ones) can greatly benefit others wanting to use the data or can help researchers developing LUCC projections better meet the needs of data users (Titeux et al. 2016).

Second, our results call on researchers using LUCC projections for BES assessments for a more comprehensive exploration of the uncertainties that relate LUCC and BES futures (Fig. 1, P2). This is critical because most studies focus solely on the uncertainties associated with multiple LUCC storylines. They generally omit other sources of uncertainties such as uncertainty associated with different LUCC models (i.e. they use projections from a single family) that represent a large part of the overall uncertainties associated to land use futures due to their different assumptions and parameterizing (Prestele et al. 2016). The so-called marker scenarios offer a first opportunity in this direction (e.g. Kim et al. 2018). However, although they cover nearly the full spectrum of LUCC in the SSP scenario set (Popp et al. 2017), they still provide for each of the five SSPs, the implementation by only one specific LUCC model; which precludes disentangling the modelling from the socioeconomic uncertainties in BES futures. LUCC-driven BES assessments should start evaluating uncertainties more thoroughly, i.e. combine different storylines, different LUCC models, and different biodiversity modelling options. Studies dealing with uncertainties in climate-driven BES futures already offer valuable frameworks to analyze and report these uncertainties (Thuiller et al. 2019), for instance with ensemble forecasting methods (Prudhomme et al. 2014). While this recommendation is difficult to put into practice due to the low availability of adequate data, it is necessary to start its implementation with what exists.

Third, our results call for the urgent development of standards and procedures to reconnect local/subnational with national/global-scale LUCC-driven BES assessments, as we found little connections between the LUCC projections used at these levels (Fig. 1, P3). Subnational/local assessments can rely on global LUCC projections as do national/global assessments, but they generally rely on three other types of projections: hypothetical scenarios (i.e. no implications for decision-making), global LUCC projections used as boundary conditions within which local futures can unfold (Biggs et al. 2007), or locally defined LUCC projections (i.e. based on participatory approaches or local development plans). The last two cases are the most interesting to enrich national/global assessments back with local specificities and knowledge as ambitioned by the IPBES (Rosa et al. 2017). Yet, ensuring that local scenarios are comparable across sites, and informative at broader scale, without jeopardizing their subnational/local relevance is not straightforward. This requires guidelines to (1) facilitate the adaptation or creation of scenarios that meet local specificities and top-down general constraints: when stakeholder-based downscaling may lead to better suited scenarios than statistical downscaling, it can also be more cumbersome (Houet et al. 2017); (2) help relate these new scenarios to existing archetypes*, i.e. groups of scenarios that share similar underlying assumptions and cover the range of possible futures (Hunt et al. 2012), with methods to establish equivalence and consistency among sets of storylines (Kok et al. 2018), even if they do not match all the characteristics of the archetype defined; and (3) define standards of documentation and archiving to help data reuse and bottom-up synthesis.

These different actions should empower ecologists' sense of ownership of LUCC scenarios and projections and greatly strengthen LUCC-based BES assessments at all scales.

Acknowledgements This work contributes to the Labex OT-Med (no. ANR-11-LABX-0061) funded by the French Government "Investissements d'Avenir" program of the French National Research Agency (ANR) through the A*MIDEX project (no. ANR-11-IDEX0001-02). We thank N. Dendoncker (Université de Namur, Belgium) and S. Zaehle (Max Planck Institute for Biogeochemistry, Germany) for the data on ALARM and ATEAM scenarios, E. Naiken for his help with the literature review, and F. Jabot for his friendly review of our manuscript. 


\section{Glossary}

Archetype

Backcasting

Baseline

Business as

usual

Downscaling

Driver, driving

force

Extrapolation

Family

Foresight,

Prospective
A storyline that is considered to be a perfect or typical example of a particular set of possible futures, because it has all their most important characteristics. Scenarios that have similar storylines could be grouped into few general archetypes.

Process of working backwards from the definition of a possible future (typically a vision), in order to determine what needs to happen to make this future unfold and connect to the present (typically a pathway).

Set of reference data used to represent the initial conditions and that serve as a basis to compare alternative scenarios.

Scenario of - or pathway towards - a future considered to be the continuation of the current path.

The process of refining the spatial grain (resolution). For LUCC, downscaling means also incorporating more information on local constraints.

The underlying causes of change, affecting or shaping the future. For instance, can be a social (e.g. human population, inequalities), economic (e.g. prices), policy governance (e.g. fair-trade vs. market-based), technological (e.g. rate of innovation), or environmental (e.g. atmospheric $\mathrm{CO}_{2}$ ) factor.

Application of a method or conclusion to a new situation assuming that existing trends will continue.

Set of projections that comes from a given modelling team, a modelling framework, or a given research project. Note that our definition differs from the IPCC acception in which families are groups of scenarios following a given storyline (see "archetype").

A systematic and multi-disciplinary approach to explore a multitude of mid- to long-term possible futures and drivers of change. Can be used as a guide in formulating public policy.
Participatory

Pathway,

Trajectory

Plausible

Projection

Scenario

Storyline, Narrative

Thematic resolution

Time horizon, timeFarthest point in the future to be frame considered (e.g. 2080); complete period (past-to-future) of time considered.

Vision The concise description of what the world might look like at some future time. A consensus can be drawn for a preferred and inspiring future, and a full strategy developed to reach this future (e.g. normative scenario). 


\section{References}

Alexander P, Prestele R, Verburg PH, Arneth A, Baranzelli C, Batista e Silva F, Brown C, Butler A, Calvin K, Dendoncker N, Doelman JC, Dunford R, Engstrom K, Eitelberg D, Fujimori S, Harrison PA, Hasegawa T, Havlik P, Holzhauer S, Humpenoder F, JacobsCrisoni C, Jain AK, Krisztin T, Kyle P, Lavalle C, Lenton T, Liu J, Meiyappan P, Popp A, Powell T, Sands RD, Schaldach R, Stehfest E, Steinbuks J, Tabeau A, Van Meijl H, Wise MA, Rounsevell MDA (2017) Assessing uncertainties in land cover projections. Glob Change Biol 23:767-781. https://doi.org/10.1111/ gcb. 13447

Biggs R, Raudsepp-Hearne C, Atkinson-Palombo C, Bohensky E, Boyd E, Cundill G, Fox H, Ingram S, Kok K, Spehar S, Tengö M,Timmer D, Zurek M (2007) Linking futures across scales: a dialog on multiscale scenarios. Ecol Soc 12:17. http://www. ecologyandsociety.org/vol12/iss1/art17/

Brockerhoff EG, Jactel H, Parrotta JA, Quine CP, Sayer J (2008) Plantation forests and biodiversity: oxymoron or opportunity? Biodivers Conserv 17:925-951. https://doi.org/10.1007/s10531008-9380-x

Brunner SH, Huber R, Grêt-Regamey A (2016) A backcasting approach for matching regional ecosystem services supply and demand. Environ Model Softw 75:439-458. https://doi.org/10.1016/j. envsoft.2015.10.018

Dale VH, Pearson SM, Offerman HL, O’Neill RV (1994) Relating patterns of land-use change to faunal biodiversity in the Central Amazon. Conserv Biol 8:1027-1036. https://doi.org/10.1046/j. 1523-1739.1994.08041027.x

de Chazal J, Rounsevell MDA (2009) Land-use and climate change within assessments of biodiversity change: a review. Glob Environ Change 19:306-315. https://doi.org/10.1016/j.gloenvcha.2008.09. 007

Dendoncker N, Bogaert P, Rounsevell MDA (2006) A statistical method to downscale aggregated land use data and scenarios. J Land Use Sci 1:63-82. https://doi.org/10.1080/17474230601058302

Dislich C, Hettig E, Salecker J, Heinonen J, Lay J, Meyer KM, Wiegand $\mathrm{K}$, Tarigan S (2018) Land-use change in oil palm dominated tropical landscapes - an agent-based model to explore ecological and socioeconomic trade-offs. PLoS One 13:1-20. https://doi.org/10.1371/ journal.pone. 0190506

Eigenbrod F, Bell VA, Davies HN, Heinemeyer A, Armsworth PR, Gaston KJ (2011) The impact of projected increases in urbanization on ecosystem services. Proc R Soc B-Biol Sci 278:3201-3208. https://doi.org/10.1098/rspb.2010.2754

Galvani AP, Bauch CT, Anand M, Singer BH, Levin SA (2016) Humanenvironment interactions in population and ecosystem health. Proc Natl Acad Sci 113:14502-14506. https://doi.org/10.1073/pnas. 1618138113

Gil-Tena A, Lecerf R, Ernoult A (2013) Disentangling community assemblages to depict an indicator of biological connectivity: a regional study of fragmented semi-natural grasslands. Ecol Indic 24:4855. https://doi.org/10.1016/j.ecolind.2012.05.022

Gonzalez A, Thompson P, Loreau M (2017) Spatial ecological networks: planning for sustainability in the long-term. Curr Opin Environ Sustain 29:187-197. https://doi.org/10.1016/j.cosust.2018.03.012

Graham LJ, Haines-Young RH, Field R (2017) Metapopulation modelling of long-term urban habitat-loss scenarios. Landsc Ecol 32:9891003. https://doi.org/10.1007/s10980-017-0504-0

Groeneveld J, Müller B, Buchmann CM, Dressler G, Guoc C, Hase N, Hoffmann F, John F, Klassert C, Laufe T, Liebelt V, Nolzen H, Pannicke N, Schulze J, Weiseg H, Schwarz N (2017) Theoretical foundations of human decision-making in agent-based land use models - a review. Environ Model Softw 87:39-48. https://doi. org/10.1016/j.envsoft.2016.10.008

Harfoot M, Tittensor DP, Newbold T, McInerny G, Smith MJ, Scharlemann JPW (2014) Integrated assessment models for ecologists: the present and the future. Glob Ecol Biogeogr 23:124-143. https://doi.org/10.1111/geb.12100

Harmáčková ZV, Vačkář D (2018) Future uncertainty in scenarios of ecosystem services provision: linking differences among narratives and outcomes. Ecosyst Serv 33:134-145. https://doi.org/10.1016/j. ecoser.2018.06.005

Hervé M, Albert CH, Bondeau A (2016) On the importance of taking into account agricultural practices when defining conservation priorities for regional planning. J Nat Conserv 33:76-84. https://doi.org/10. 1016/j.jnc.2016.08.001

Houet T, Grémont M, Vacquié L, Forget Y, Marriotti A, Puissant A, Bernardie S, Thiery Y, Vandromme R, Grandjean G (2017) Downscaling scenarios of future land use and land cover changes using a participatory approach: an application to mountain risk assessment in the Pyrenees (France). Reg Environ Chang. 17:2293$2307 \mathrm{https}: / /$ doi.org/10.1007/s10113-017-1171-z

Hunt DVL, Lombardi DR, Atkinson S, Barber ARG, Barnes M, Boyko CT, Brown J, Bryson J, Butler D, Caputo S, Caserio M, Coles R, Cooper RFD, Farmani R, Gaterell M, Hale J, Hales C, Hewitt CN, Jankovic L, Jefferson I, Leach J, MacKenzie AR, Memon FA, Sadler JP, Weingaertner C, Whyatt JD, Rogers CDF (2012) Scenario archetypes: converging rather than diverging themes. Sustainability 4:740-772. https://doi.org/10.3390/su4040740

Hurtt GC, Chini LP, Frolking S, Betts RA, Feddema J, Fischer G, Fisk JP, Hibbard K, Houghton RA, Janetos A, Jones CD, Kindermann G, Kinoshita T, Goldewijk KK, Riahi K, Shevliakova E, Smith S, Stehfest E, Thomson A, Thornton P, van Vuuren DP, Wang YP (2011) Harmonization of land-use scenarios for the period 1500 2100: 600 years of global gridded annual land-use transitions, wood harvest, and resulting secondary lands. Clim Chang 109:117. https:// doi.org/10.1007/s10584-011-0153-2

IPBES (2016) The methodological assessment report on scenarios and models of biodiversity and ecosystem services. S. Ferrier, K. N. Ninan, P. Leadley, R. Alkemade, L.A. Acosta, H. R. Akçakaya, L. Brotons, W. Cheung, V. Christensen, K. A. Harhash, J. KabuboMariara, C. Lundquist, M. Obersteiner, H. Pereira, G. Peterson, R. Pichs-Madruga, N. H. Ravindranath, C. Rondinini, B. Wintle, Secretariat of the Intergovernmental Science-Policy Platform on Biodiversity and Ecosystem Services, Bonn, Germany

IPBES (2019) Global assessment report on biodiversity and ecosystem services of the Intergovernmental Science-Policy Platform on Biodiversity and Ecosystem Services. E. S. Brondizio, J. Settele, S. Díaz, and H. T. Ngo (editors). IPBES secretariat, Bonn, Germany

IPCC (2014) Climate change 2014: synthesis report. Contribution of Working Groups I, II and III to the Fifth Assessment Report of the Intergovernmental Panel on Climate Change, IPCC. Core Writing Team, R.K. Pachauri and L.A. Meyer, Geneva, Switzerland

Jepsen MR, Kuemmerle T, Müller D, Erb K, Verburg PH, Haberl H, Vesterager JP, Andric M, Antrop M, Austrheim G, Björn I, Bondeau A, Bürgi M, Bryson J, Caspar G, Cassar LF, Conrad E, Chromy P, Daugirdas V, Van Eetvelde V, Elena-Rosselló R, Gimmi U, Izakovicova Z, Jancák V, Jansson U, Kladnik D, Kozak J, Konkoly-Gyuró E, Krausmann F, Mander U, McDonagh J, Pärn J, Niedertscheider M, Nikodemus O, Ostapowicz K, Pérez-Soba M, Pinto-Correia T, Ribokas G, Rounsevell MDA, Schistou D, Schmit C, Terkenli TS, Tretvik AM, Trzepacz P, Vadineanu A, Walz A, Zhllima E, Reenberg A (2015) Transitions in European landmanagement regimes between 1800 and 2010. Land Use Policy 49:53-64. https://doi.org/10.1016/j.landusepol.2015.07.003

Jiang W, Deng Y, Tang Z, Lei X, Chen Z (2017) Modelling the potential impacts of urban ecosystem changes on carbon storage under different scenarios by linking the CLUE-S and the InVEST models. 
Ecol Model 345:30-40. https://doi.org/10.1016/j.ecolmodel.2016. 12.002

Kim H, Rosa IMD, Alkemade R, Leadley P, Hurtt G, Popp A, van Vuuren DP, Anthoni P, Arneth A, Baisero D, Caton E, ChaplinKramer R, Chini L, De Palma A, Di Fulvio F, Di Marco M, Espinoza F, Ferrier S, Fujimori S, Gonzalez RE, Gueguen M, Guerra C, Harfoot M, Harwood TD, Hasegawa T, Haverd V, Havlík P, Hellweg S, Hill SLL, Hirata A, Hoskins AJ, Janse JH, Jetz W, Johnson JA, Krause A, Leclère D, Martins IS, Matsui T, Merow C, Obersteiner M, Ohashi H, Poulter B, Purvis A, Quesada B, Rondinini C, Schipper AM, Sharp R, Takahashi K, Thuiller W, Titeux N, Visconti P, Ware C, Wolf F, Pereira HM (2018) A protocol for an intercomparison of biodiversity and ecosystem services models using harmonized land-use and climate scenarios. Geosci Model Dev 11:4537-4562. https://doi.org/10.5194/gmd-11-45372018

Kok K, Pedde S, Gramberger M, Harrison PA, Holman IP (2018) New European socio-economic scenarios for climate change research: operationalising concepts to extend the shared socio-economic pathways. Reg Environ Chang 19: 643-654 https://doi.org/10.1007/ s10113-018-1400-0

Kok MTJ, Kok K, Peterson GD, Hill R, Agard J, Carpenter SR (2017) Biodiversity and ecosystem services require IPBES to take novel approach to scenarios. Sustain Sci 12:177-181. https://doi.org/10. 1007/s11625-016-0354-8

Kuemmerle T, Levers C, Erb K, Estel S, Jepsen MR, Müller D, Plutzar C, Stürck J, Verkerk PJ, Verburg PH, Reenberg A (2016) Hotspots of land use change in Europe. Environ Res Lett 11:064020. https://doi. org/10.1088/1748-9326/11/6/064020

McPherson JM, Jetz W, Rogers DJ (2006) Using coarse-grained occurrence data to predict species distributions at finer spatial resolutions - possibilities and limitations. Ecol Model 192:499522. https://doi.org/10.1016/j.ecolmodel.2005.08.007

Metzger MJ, Leemans R, Schröter D, Cramer W (2004) The ATEAM vulnerability mapping tool: explore the vulnerability of different sectors to global change impacts in Europe. C.T. de Wit Graduate School for Production Ecology \& Resource Conservation (PE \& RC), Wageningen

Millennium Ecosystem Assessment (2005) Ecosystems and human wellbeing. Island Press, USA

Morán-Ordóñez A, Roces-Díaz JV, Otsu K, Ameztegui A, Coll L, Lefevre F, Retana J, Brotons L (2018) The use of scenarios and models to evaluate the future of nature values and ecosystem services in Mediterranean forests. Reg Environ Chang. 19:415-428 https://doi.org/10.1007/s10113-018-1408-5

Nakićenović N and Swart R (2000) Special report on emissions scenarios, intergovernmental panel on climate change, Cambridge University Press. Cambridge, United Kingdom and New York

Newbold T, Hudson LN, Arnell AP, Contu S, De Palma A, Ferrier S, Hill SLL, Hoskins AJ, Lysenko I, Phillips HRP, Burton VJ, Chang CWT, Emerson S, Gao D, Pask-Hale G, Hutton J, Jung M, Sanchez-Ortiz K, Simmons BI, Whitmee S, Zhang H, Scharlemann JPW, Purvis A (2016) Has land use pushed terrestrial biodiversity beyond the planetary boundary? A global assessment. Science 353:288-291. https://doi.org/10.1126/science.aaf2201

O’Neill BC, Kriegler E, Ebi KL, Kemp-Benedict E, Riahi K, Rothman DS, van Ruijven BJ, van Vuuren DP, Birkmann J, Kok K, Levy M, Solecki W (2017) The roads ahead: narratives for shared socioeconomic pathways describing world futures in the 21 st century. Glob Environ Change 42:169-180. https://doi.org/10.1016/j.gloenvcha. 2015.01.004

Opdam P, Wascher D (2004) Climate change meets habitat fragmentation: linking landscape and biogeographical scale levels in research and conservation. Biol Conserv 117:285-297. https://doi.org/10. 1016/j.biocon.2003.12.008
Pereira HM, Leadley PW, Proença V, Alkemade R, Scharlemann JPW, Fernandez-Manjarrés JF, Araújo MB, Balvanera P, Biggs R, Cheung WWL, Chini L, Cooper HD, Gilman EL, Guénette S, Hurtt GC, Huntington HP, Mace GM, Oberdorff T, Revenga C, Rodrigues P, Scholes RJ, Sumaila UR, Walpole M (2010) Scenarios for global biodiversity in the 21 st century. Science 330 : 1496-1501. https://doi.org/10.1126/science.1196624

Petchey OL, Pontarp M, Massie TM, Kefi S, Ozgul A, Weilenman M, Palamara GM, Altermatt F, Blake M, Levine JM, Childs DZ, McGill BJ, Schaepman ME, Schmid B, Spaak P, Beckerman AP, Pennekamp F, Pearse IS (2015) The ecological forecast horizon, and examples of its uses and determinants. Ecol Lett 18:597-611. https://doi.org/10.1111/ele.12443

Pickard BR, Van Berkel D, Petrasova A, Meentemeyer RK (2017) Forecasts of urbanization scenarios reveal trade-offs between landscape change and ecosystem services. Landsc Ecol 32:617-634. https://doi.org/10.1007/s10980-016-0465-8

Plieninger T, Draux H, Fagerholm N, Bieling C, Bürgi M, Kizose T, Kuemmerle T, Primdahl J, Verburg PH (2016) The driving forces of landscape change in Europe: a systematic review of the evidence. Land Use Policy 57:204-214. https://doi.org/10.1016/j.landusepol. 2016.04.040

Popp A, Calvin K, Fujimori S, Havlik P, Humpenöder F, Stehfest E, Leon Bodirsky B, Dietrich JP, Doelmann J, Gusti M, Hasegawa T, Kyle P, Obersteiner M, Tabeau A, Takahashi A, Valin H, Waldhoff S, Weindla I, Wise M, Kriegler E, Lotze-Campena H, Fricko O, Riahid K, vanVuuren DP (2017) Land-use futures in the shared socioeconomic pathways. Glob Environ Change 42:331-345. https:// doi.org/10.1016/j.gloenvcha.2016.10.002

Prestele R, Alexander P, Rounsevell MDA, Arneth A, Calvin K, Doelman J, Eitelberg DA, Engström K, Fujimori S, Hasegawa T, Havlik P, Humpenöder F, Jain AK, Krisztin T, Kyle P, Meiyappan P, Popp A, Sands RD, Schaldach R, Schüngel J, Stehfest E, Tabeau A, Meijl HV, Van Vliet J, Verburg PH (2016) Hotspots of uncertainty in land-use and land-cover change projections: a global-scale model comparison. Glob Change Biol 22:3967-3983. https://doi. org $/ 10.1111 /$ gcb.13337

Prudhomme C, Giuntoli I, Robinson EL, Clark DB, Arnell NW, Dankers R, Fekete BM, Franssen W, Gerten D, Gosling SN, Hagemann S, Hannah DM, Kim H, Masaki Y, Satoh Y, Stacke T, Wada Y, Wisser D (2014) Hydrological droughts in the 21st century, hotspots and uncertainties from a global multimodel ensemble experiment. Proc Natl Acad Sci 111:3262-3267. https://doi.org/10.1073/pnas. 1222473110

Radinger J, Hölker F, Horký P, Slavik O, Dendoncker N, Wolter C (2016) Synergistic and antagonistic interactions of future land use and climate change on river fish assemblages. Glob Change Biol 22: 1505-1522. https://doi.org/10.1111/gcb.13183

Rickebusch S, Metzger MJ, Xu G, Vogiatzakis IN, Potts SP, Stirpe MT, Rounsevell MDA (2011) A qualitative method for the spatial and thematic downscaling of land-use change scenarios. Environ Sci Pol 14:268-278. https://doi.org/10.1016/j.envsci.2010.11.003

Riordan EC, Gillespie TW, Pitcher L, Pincetl SS, Jenerette GD, Pataki DE (2015) Threats of future climate change and land use to vulnerable tree species native to Southern California. Environ Conserv 42: 127-138. https://doi.org/10.1017/S0376892914000265

Rosa IMD, Pereira HM, Ferrier S, Alkemade R, Acosta LA, Akcakaya HR, den Belder E, Fazel AM, Fujimori S, Harfoot M, Harhash KA, Harrison PA, Hauck J, Hendriks RJJ, Hernández G, Jetz W, Karlsson-Vinkhuyzen SI, Kim HJ, King N, Kok MTJ, Kolomytsev GO, Lazarova T, Leadley P, Lundquist CJ, García Márquez J, Meyer C, Navarro LM, Nesshöver C, Ngo HT, Ninan KN, Palomo MG, Pereira LM, Peterson GD, Richs R, Popp A, Purvis A, Ravera F, Rondinini C, Sathyapalan J, Schipper AM, Seppelt R, Settele J, Sitas N, van Vuuren D (2017) Multiscale 
scenarios for nature futures. Nat Ecol Evol 1:1416-1419. https://doi. org/10.1038/s41559-017-0273-9

Rounsevell MDA, Metzger MJ (2010) Developing qualitative scenario storylines for environmental change assessment: developing qualitative scenario storylines. Wiley Interdiscip Rev Clim Chang 1:606619. https://doi.org/10.1002/wcc.63

Schmitz C, van Meijl H, Kyle P, Nelson GC, Fujimori S, Gurgel A, Havlik P, Heyhoe E, d'Croz DM, Popp A, Sands R, Tabeau A, van der Mensbrugghe $\mathrm{D}$, von Lampe $\mathrm{M}$, Wise M, Blanc $\mathrm{E}$, Hasegawa T, Kavallari A, Valin H (2014) Land-use change trajectories up to 2050: insights from a global agro-economic model comparison. Agric Econ 45:69-84. https://doi.org/10.1111/agec.12090

Schulze J, Frank K, Priess JA, Meyer MA (2016) Assessing regionalscale impacts of short rotation coppices on ecosystem services by modeling land-use decisions. PLoS One 11:e0153862. https://doi. org/10.1371/journal.pone. 0153862

Seto KC, Guneralp B, Hutyra LR (2012) Global forecasts of urban expansion to 2030 and direct impacts on biodiversity and carbon pools. Proc Natl Acad Sci 109:16083-16088. https://doi.org/10.1073/pnas. 1211658109

Sexton JO, Noojipady P, Song XP, Feng M, Song DX, Kim DH, Anand A, Huang C, Channan S, Pimm SL, Townshend JR (2016) Conservation policy and the measurement of forests. Nat Clim Chang 6:192-196. https://doi.org/10.1038/nclimate2816

Sirami C, Caplat P, Popy S, Clamens A, Arlettaz R, Jiguet F, Brotons L, Martin JL (2017) Impacts of global change on species distributions: obstacles and solutions to integrate climate and land use. Glob Ecol Biogeogr 26:385-394. https://doi.org/10.1111/geb.12555

Sohl TL, Wimberly MC, Radeloff VC, Theobald DM, Sleeter BM (2016) Divergent projections of future land use in the United States arising from different models and scenarios. Ecol Model 337:281-297. https://doi.org/10.1016/j.ecolmodel.2016.07.016

Spangenberg JH, Bondeau A, Carter TR, Fronzek S, Jaeger J, Jylhä K, Kühn I, Omann I, Paul A, Reginster I, Rounsevell M, Schweiger O, Stocker A, Sykes MT, Settele J (2012) Scenarios for investigating risks to biodiversity. Glob Ecol Biogeogr 21:5-18. https://doi.org/ 10.1111/j.1466-8238.2010.00620.x

Stehfest E, van Zeist WJ, Valin H, Havlik P, Popp A, Kyle P, Tabeau A, Mason-D'Croz D, Hasegawa T, Bodirsky BL, Calvin K, Doelman JC, Fujimori S, Humpenöder F, Lotze-Campen H, van Meijl H, Wiebe K (2019) Key determinants of global land-use projections. Nat Commun 10:2166. https://doi.org/10.1038/s41467-019-09945$\mathrm{w}$

Sushinsky JR, Rhodes JR, Possingham HP, Gill TK, Fuller RA (2013) How should we grow cities to minimize their biodiversity impacts? Glob Change Biol 19:401-410. https://doi.org/10.1111/gcb.12055

Synes NW, Brown C, Palmer SCF, Bocedi G, Osborne PE, Watts K, Franklin J, Travis JMJ (2019) Coupled land use and ecological models reveal emergence and feedbacks in socio-ecological systems. Ecography 42:814-825. https://doi.org/10.1111/ecog.04039

Thompson JR, Lambert KF, Foster DR, Broadbent EN, Blumstein M, Almeyda Zambrano AM, Fan Y (2016) The consequences of four land-use scenarios for forest ecosystems and the services they provide. Ecosphere 7:1-22. https://doi.org/10.1002/ecs2.1469

Thuiller W, Albert CH, Araújo MB, Berry PM, Cabeza M, Guisan A, Hickler T, Midgley GF, Paterson J, Schurr FM, Sykes MT, Zimmermann NE (2008) Predicting global change impacts on plant species' distributions: future challenges. Perspect Plant Ecol Evol Syst 9:137-152. https://doi.org/10.1016/j.ppees.2007.09.004

Thuiller W, Guéguen M, Renaud J, Karger DN, Zimmermann N (2019) Uncertainty in ensembles of global biodiversity scenarios. Nat Commun 10. https://doi.org/10.1038/s41467-019-09519-w

Titeux N, Henle K, Mihoub JB, Regos A, Geijzendorffer IR, Cramer W, Verburg PH, Brotons L (2016) Biodiversity scenarios neglect future land-use changes. Glob Change Biol 22:2505-2515. https://doi.org/ $10.1111 /$ gcb. 13272

Torres A, Jaeger JAG, Alonso JC (2016) Assessing large-scale wildlife responses to human infrastructure development. Proc Natl Acad Sci U S Am Proc Natl Acad Sci U S Am 113 113(8472):8472-8477. https://doi.org/10.1073/pnas.1522488113

Urban MC, Bocedi G, Hendry AP, Mihoub JB, Pe'er G, Singer A, Bridle JR, Crozier LG, De Meester L, Godsoe W, Gonzalez A, Hellmann JJ, Holt RD, Huth A, Johst K, Krug CB, Leadley PW, Palmer SCF, Pantel JH, Schmitz A, Zollner PA, Travis JMJ (2016) Improving the forecast for biodiversity under climate change. Science 353: aad8466. https://doi.org/10.1126/science.aad8466

Van Asselen S, Verburg PH (2013) Land cover change or land-use intensification: simulating land system change with a global-scale land change model. Glob Change Biol 19:3648-3667. https://doi.org/10. $1111 / \mathrm{gcb} .12331$

Visconti P, Bakkenes M, Baisero D, Brooks T, Butchart SHM, Joppa L, Alkemade R, Di Marco M, Santini L, Hoffmann M, Maiorano L, Pressey RL, Arponen A, Boitani L, Reside AE, van Vuuren DP, Rondinini C (2016) Projecting global biodiversity indicators under future development scenarios. Conserv Lett 9:5-13. https://doi.org/ $10.1111 /$ conl.12159

Voiron-Canicio C (2012) L'anticipation du changement en prospective et des changements spatiaux en géoprospective. Espace Géographique 41:99. https://doi.org/10.3917/eg.412.0099

Wilkinson MD, Dumontier M, Aalbersberg IJ, Appleton G, Axton M, Baak A, Blomberg N, Boiten JW, da Silva Santos LB, Bourne PE, Bouwman J, Brookes AJ, Clark T, Crosas M, Dillo I, Dumon O, Edmunds S, Evelo CT, Finkers R, Gonzalez-Beltran A, AJG Gray, Groth P, Goble C, Grethe JS, Heringa J, Hoen PAC, Hooft R, Kuhn T, Kok R, Kok J, Lusher SC, Martone ME, Mons A, Packer AL, Persson B, Rocca-Serra P, Roos M, van Schaik R, Sansone SA, Schultes E, Sengstag T, Slater T, Strawn G, Swertz MA, Thompson M, van der Lei J, van Mulligen E, Velterop J, Waagmeester A, Wittenburg P, Wolstencroft P, Zhao J, Mons B (2016) The FAIR Guiding Principles for scientific data management and stewardship. Sci Data 3:160018. https://doi.org/10.1038/sdata. 2016.18

Zarandian A, Baral H, Stork NE, Ling MA, Yavari AR, Jafari HR, Amirnejad H (2017) Modeling of ecosystem services informs spatial planning in lands adjacent to the Sarvelat and Javaherdasht protected area in northern Iran. Land Use Policy 61:487-500. https://doi.org/ 10.1016/j.landusepol.2016.12.003

Zhou ZX, Li J, Guo ZZ, Li T (2017) Trade-offs between carbon, water, soil and food in Guanzhong-Tianshui economic region from remotely sensed data. Int J Appl Earth Obs Geoinformation 58:145-156. https://doi.org/10.1016/j.jag.2017.01.003 